\title{
Comparison of organic and conventional managements on yields, nutrients and weeds in a corn-cabbage rotation
}

\author{
Yadunath Bajgai ${ }^{1,2 *}$, Paul Kristiansen ${ }^{1}$, Nilantha Hulugalle ${ }^{3}$ and Melinda McHenry ${ }^{4}$ \\ ${ }^{1}$ School of Environmental and Rural Science, University of New England, Armidale, NSW 2351, Australia. \\ ${ }^{2}$ Renewable Natural Resources, Research and Development Centre Bajo, Department of Agriculture, \\ MoAF, Bhutan. \\ ${ }^{3}$ New South Wales Department of Primary Industries, NSW 2390, Narrabri, Australia. \\ ${ }^{4}$ Centre for Plant and Water Sciences, Central Queensland University, QLD 4670, Bundaberg, Australia. \\ *Corresponding author: ybajgai@gmail.com
}

\begin{abstract}
Conventional soil management systems (SMS) use synthetic inputs to maximize crop productivity, which leads to environmental degradation. Organic SMS is an alternative that is claimed to prevent or mitigate such negative environmental impacts. Vegetable production systems rely on frequent tillage to prepare beds and manage weeds, and are also characterized by little crop residue input. The use of crop residues and organic fertilizers may counteract the negative impacts of intensive vegetable production. To test this hypothesis, we evaluated the effect of sweet corn (Zea mays $\mathrm{L}$. var. rugosa) residue incorporation in a corn-cabbage (Brassica oleracea L.) rotation on crop yields, nutrient uptake, weed biomass and soil nutrients for organic and conventional SMS in two contrasting soil types (a Chromosol and a Vertosol). Yields of corn and cabbage under the organic SMS were not lower than the conventional SMS, possibly due to the equivalent N, P and K nutrients applied. Macro-nutrient uptake between the organic and conventional SMS did not differ for cabbage heads. Corn residue incorporation reduced the average in-crop weed biomass in cabbage crops by $22 \%$ in 2010 and by $47 \%$ in 2011. Corn residue-induced inhibitions on weed biomass may be exploited as a supplementary tool to mechanical weed control for the organic SMS, potentially reducing the negative impacts of cultivation on soil organic carbon. Residue incorporation and the organic SMS increased the average total soil $\mathrm{N}$ by 7 and $4 \%$ compared with the treatments without residue and the conventional SMS, respectively, indicating the longer-term fertility gains of these treatments. Exchangeable K, but not Colwell $\mathrm{P}$, in the soil was significantly increased by residue incorporation. The clayey Vertosol conserved higher levels of nutrients than the sandy Chromosol. Yields under organic SMS can match that of conventional SMS. Residue incorporation in soil improved soil nutrients and reduced weed biomass.
\end{abstract}

Key words: residue incorporation, Vertosol, Chromosol, atrazine, cultivation

\section{Introduction}

Concerns about declining soil organic $\mathrm{C}$ (SOC) and increased greenhouse gas emissions due to farming practices such as intensive tillage, excessive rates of $\mathrm{N}$ fertilizer and bare fallows have encouraged adoption of conservation agricultural practices such as no-tillage, crop rotations and residue retention ${ }^{1,2}$. However, while no-till farming is suited for broadacre crops it is unsuitable for most vegetable crops. The latter rely on tillage to perform basic management operations such as preparation of beds and management of weeds. These tillage operations disrupt soil aggregates exposing the physically protected soil organic matter (SOM) leading to loss of $\mathrm{SOC}^{3,4}$ and declines in soil productivity.

Crop residue management plays an important role in maintaining SOC in horticulture, especially where annual crop rotations rely on frequent tillage. Residue management options include removal from the field, incorporating into the soil, burning in situ, composting or use as mulch for a succeeding $\operatorname{crop}^{5,6}$. The removal of crop residues from the field is mainly driven by the demand for other farm uses ${ }^{6,7}$ or for industrial purposes such as biofuel production ${ }^{8}$. Retention of crop residues can help increase yields, improve soil nutrients and conserve soil water in semi-arid conditions ${ }^{5,9}$. 
A vegetable system returns very small quantities of its residue, whereas at the same time it is more susceptible to soil degradation due to its dependence on heavy tillage $^{10,11}$. Organic soil management systems (SMS) use organic sources (such as crop residue and compost) for fertilization but conventional SMS use mineral fertilizers as the main source of crop nutrition ${ }^{12,13}$. Soil nutrient reserves and underlying nutrient cycling processes in organically cropped soils are similar to that in conventionally managed soils; however, the former holds nutrients in less-available forms ${ }^{14,15}$ as they are in some form of SOM, which is of greater significance.

Organic crop producers have limited tools for managing weeds unlike conventional producers who use herbicides $^{13,16}$. Weed management is ranked as the number one constraint to organic production and research on weed management is a top priority for UK farmers ${ }^{17}$. Mechanical cultivation is a common method of managing weeds in organically managed farms ${ }^{16}$ which not only impacts negatively to the SOM and soil structure, but also involves use of fossil fuel, negating the advantages of organic farming ${ }^{18}$. Hand removal of weeds is tedious and too labor intensive to be a commercially viable option. Research studies examining alternative management strategies of using cover crop residues for suppression of weeds in vegetables are reported in the literature ${ }^{19,20}$. The strategy exploits allelopathic properties of these residues to suppress weeds through the release of phytotoxins from decomposing residue ${ }^{21}$. Thus, we undertook to study the effect of corn residue incorporation on the weed biomass in a vegetable production system.

Performance of farming systems is widely assessed using crop yield as an indicator, and high yields are essential to achieving food security because land resources are finite ${ }^{22}$. Individual studies comparing yields between organic and conventional systems ${ }^{23-25}$ reported varied results from one study to another. A global scale review and synthesis by Badgley et al. ${ }^{26}$ concluded that organic agriculture balanced, or even exceeded conventional yields, and could provide sufficient food on current agricultural land. However, Trewavas ${ }^{27}$ argued that organic agriculture may have lower yields and would thus need more land to produce the same quantity of food as conventional farms. Hence, more research is needed to understand the yield differences between the two systems.

A generally held perception among food consumers is that organically produced crops possess higher nutritional quality than those produced conventionally ${ }^{28}$. However, the literature on food nutrition reports a lack of clear, consistent differences between the nutrient contents of organic and conventional produce ${ }^{29,30}$.

The focus of this paper is on understanding the plant and soil responses to residue incorporation (in organic and conventional SMS), using sweet corn (Zea mays L. var. rugosa)/cabbage (Brassica oleracea $\mathrm{L}$.) as a model through a 2-year field trial. Annual sweet corn production is estimated at $62,575 \mathrm{t}$ from a total area of $5942 \mathrm{ha}$ and the
Table 1. Mean values for selected soil properties for $0-0.1 \mathrm{~m}$ depth of field trial sites $(n=4)$.

\begin{tabular}{lccc}
\hline Soil property & Units & Chromosol & Vertosol \\
\hline Total organic C & & 1.28 & 2.41 \\
Total N & & 0.13 & 0.2 \\
Sand & ${\mathrm{g} 100 \mathrm{~g}^{-1}}$ & 74.3 & 22.4 \\
Silt & & 10.6 & 15.6 \\
Clay & & 14.5 & 62.3 \\
Exchangeable K & & 0.38 & 0.59 \\
Exchangeable Ca & & 1.74 & 21.71 \\
Exchangeable $\mathrm{Mg}$ & $\mathrm{cmol}_{\mathrm{c}} \mathrm{kg}^{-1}$ & 0.65 & 12.9 \\
Exchangeable Na & & 0.07 & 0.18 \\
Bulk density & $\mathrm{Mg} \mathrm{m}^{-3}$ & 1.47 & 1.22 \\
$\mathrm{pH}\left(\mathrm{H}_{2} \mathrm{O}\right)_{1: 5}$ & & 5.6 & 5.5 \\
\hline
\end{tabular}

annual cabbage production is estimated at $81,563 \mathrm{t}$ from a total area of 2020 ha in Australia ${ }^{31}$.

The specific objectives were to examine the effect of organic and conventional SMS with corn residue management (incorporation $=+$ RES or removal $=-\mathrm{RES}$ ) on Australian vegetable production:

(a) yields and biomass production of sweet corn and cabbage,

(b) nutrient uptake by cabbage heads,

(c) in-crop weed biomass in cabbage, and

(d) soil nutrients.

\section{Materials and Methods}

\section{Site and climate}

An SMS field trial was conducted over 24 months at two sites in the Armidale area $\left(30.48^{\circ} \mathrm{S}\right.$ and $151.65^{\circ} \mathrm{E}$, elevation $1063 \mathrm{~m}$ ) of New South Wales, Australia, with two contrasting soil types: a medium loam brown Chromosol (referred to as Chromosol) and a heavy clay black Vertosol (referred to as Vertosol) in the Australian soil classification system ${ }^{32}$ (Table 1). These correspond to Alfisol and Vertisol, respectively, in the USDA classification $^{33}$.

Monthly rainfall and minimum and maximum temperatures (daily averages) during the experiment are presented in Fig. 1 which details the climatic conditions of the two sites and was from the nearest weather station ( $\sim 5 \mathrm{~km}$ away from both trial sites). The rainfall is summer dominant with the hottest weather in the January-February period and the coldest in the June-July period $^{34}$.

\section{Experimental design and set-up}

A rotation of sweet corn (cv. Early Leaming) in summer and cabbage (cv. Sugarloaf) in winter was grown with two SMS (organic or conventional), and two residue management practices (+RES, or - RES) on both the Chromosol 
Table 2. Nutrient composition of organic and mineral fertilizers and the rates applied to corn crop.

\begin{tabular}{|c|c|c|c|c|c|c|c|c|}
\hline & \multirow{2}{*}{$\begin{array}{l}\text { Fertilizer applied } \\
\qquad\left(\mathrm{kgha}^{-1}\right)\end{array}$} & \multicolumn{7}{|c|}{ Nutrient $\left(\mathrm{kg} \mathrm{ha}^{-1}\right)$} \\
\hline & & $\mathbf{N}$ & $\mathbf{P}$ & $\mathbf{K}$ & $\mathbf{C a}$ & $\mathbf{S}$ & Mg & $\mathbf{C}$ \\
\hline \multicolumn{9}{|l|}{ Organic fertilizers } \\
\hline Organic Life Garden Food & 1000 & 40 & 30 & 20 & 48 & 0 & 0 & 233 \\
\hline New Era High N & 2000 & 160 & 20 & 20 & 20 & 5 & 3 & 752 \\
\hline Total $\left(\mathrm{kg} \mathrm{ha}^{-1}\right)$ & 3000 & 200 & 50 & 40 & 68 & 5 & 3 & 985 \\
\hline \multicolumn{9}{|l|}{ Mineral fertilizers } \\
\hline Urea & 435 & 200 & 0 & 0 & 0 & 0 & 0 & 0 \\
\hline Trifos & 242 & 0 & 50 & 0 & 36 & 24 & 0 & 0 \\
\hline Muriate of potash & 80 & 0 & 0 & 40 & 0 & 0 & 0 & 0 \\
\hline Total $\left(\mathrm{kg} \mathrm{ha}^{-1}\right)$ & 757 & 200 & 50 & 40 & 36 & 24 & 0 & 0 \\
\hline
\end{tabular}

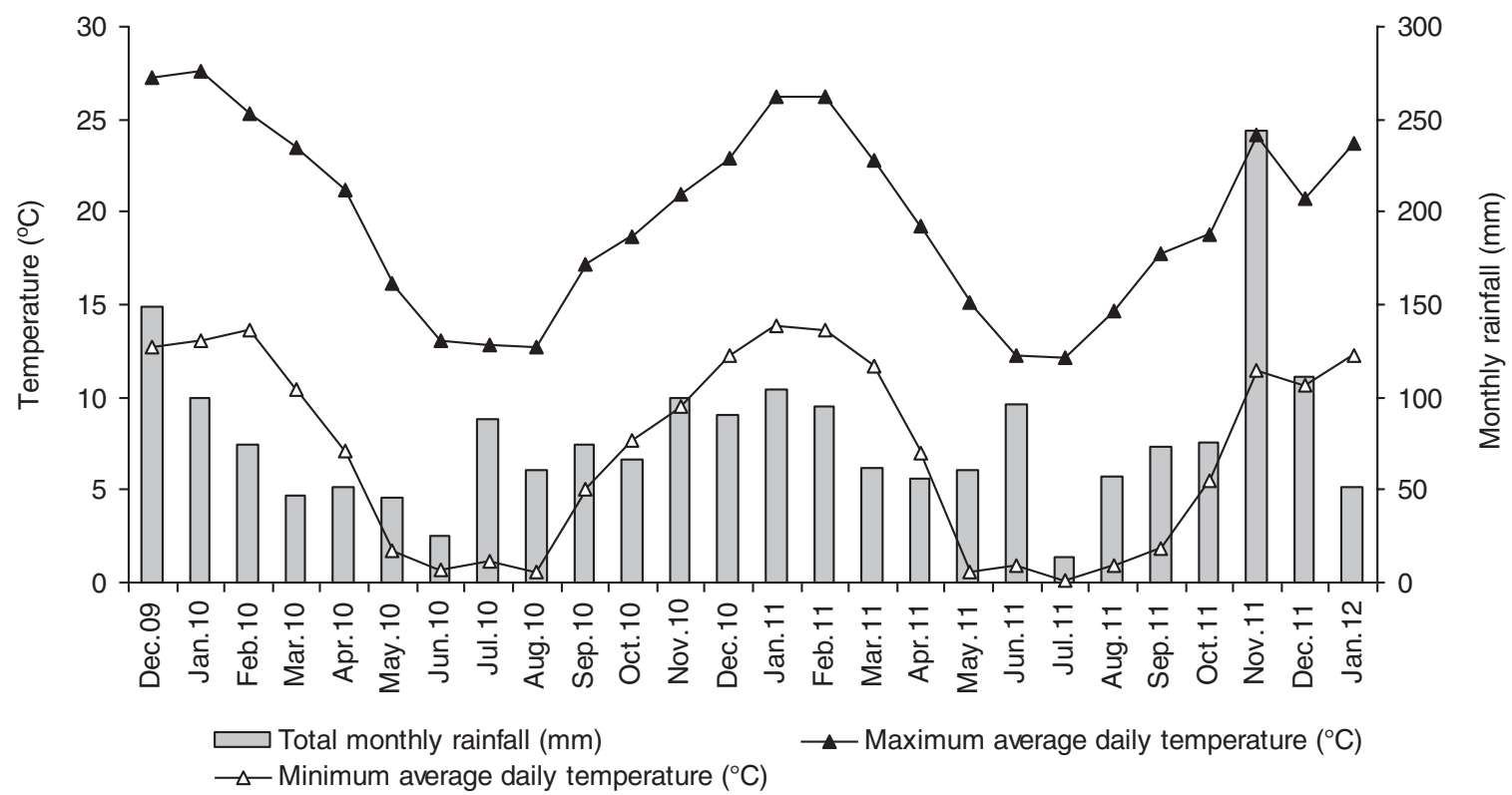

Figure 1. Monthly rainfall and minimum and maximum temperatures during the experiment.

and Vertosol sites. The experiment commenced in December 2009 and ended in December 2011 completing four cropping seasons. A randomized layout with a twoway factorial design was adopted at each site and each treatment had four replicates. Each plot was $6 \mathrm{~m} \times 2 \mathrm{~m}$. Corn was sown on December 14, 2009 and November 15, 2011 using a tractor-mounted seeder and planting density maintained at 70,000 plants ha $^{-1}$ in four rows spaced $0.5 \mathrm{~m}$ apart.

The macro-nutrients supplied to both crops by organic and mineral fertilizers ${ }^{35}$ were balanced since comparative studies on conventional and organic farming rarely balance the nutrient inputs in farming systems research ${ }^{36-38}$. Corn was fertilized in the organic and conventional SMS at the recommended rate of $200: 50: 40 \mathrm{kgha}^{-1} \mathrm{~N}: \mathrm{P}: \mathrm{K}^{39}$. The fertilizer combinations to meet the nutrient requirement for corn are in Table 2. Commercially available organic fertilizers (New Era High N and Organic Life Garden Food) were applied pre-sowing for organic SMS, whereas urea, trifos and muriate of potash were used in the conventional SMS. Half of the fertilizers were banded along the four rows and the other half spread evenly over each plot. Half of the $\mathrm{N}$ fertilizer in conventional SMS was applied at sowing and the rest as a top dressing 1 month after sowing. Weeds in organic SMS were managed using a chipping hoe at 3 and 7 weeks after sowing. Weeds in conventional SMS were managed using 2 liters ha ${ }^{-1}$ atrazine $\left(\mathrm{C}_{8} \mathrm{H}_{14} \mathrm{ClN}_{5}\right)\left(480 \mathrm{gl}^{-1}\right.$ of S-triazine as active ingredient) at pre-emergence and 3 weeks after sowing. No other crop protection was required for corn in both years. The crop was irrigated using drip irrigation. After harvesting cobs on April 23, 2010 and March 21, 2011, corn stover was shredded mechanically with a mulching machine, spread evenly across the + RES plots at $14.8 \mathrm{t}$ dry weight $\mathrm{ha}^{-1}$ (estimated average yield) and incorporated using a rotary hoe to a depth of $0.15-0.2 \mathrm{~m}$. The residue had average C:N ratios of 43:1 in 2010 and 53:1 in 2011 . 
Table 3. Nutrient composition of organic and mineral fertilizers and the rates applied to cabbage crop.

\begin{tabular}{|c|c|c|c|c|c|c|c|c|}
\hline & \multirow{2}{*}{$\begin{array}{l}\text { Fertilizer applied } \\
\qquad\left(\mathrm{kgha}^{-1}\right)\end{array}$} & \multicolumn{7}{|c|}{ Nutrient $\left(\mathrm{kg} \mathrm{ha}^{-1}\right)$} \\
\hline & & $\mathbf{N}$ & $\mathbf{P}$ & $\mathbf{K}$ & $\mathrm{Ca}$ & $\mathbf{S}$ & Mg & $\mathbf{C}$ \\
\hline \multicolumn{9}{|l|}{ Organic fertilizers } \\
\hline Organic Life Garden Food & 2000 & 80 & 60 & 40 & 96 & 0 & 0 & 467 \\
\hline New Era High N & 500 & 40 & 5 & 5 & 5 & 1 & 1 & 188 \\
\hline Gypsum & 333 & 0 & 0 & 0 & 70 & 52 & 0 & 0 \\
\hline Total $\left(\mathrm{kgha}^{-1}\right)$ & 2833 & 120 & 65 & 45 & 171 & 53 & 1 & 655 \\
\hline \multicolumn{9}{|l|}{ Mineral fertilizers } \\
\hline Urea & 261 & 120 & 0 & 0 & 0 & 0 & 0 & 0 \\
\hline Trifos & 314 & 0 & 65 & 0 & 47 & 31 & 0 & 0 \\
\hline Muriate of potash & 90 & 0 & 0 & 45 & 0 & 0 & 0 & 0 \\
\hline Gypsum & 333 & 0 & 0 & 0 & 70 & 52 & 0 & 0 \\
\hline Total $\left(\mathrm{kg} \mathrm{ha}^{-1}\right)$ & 998 & 120 & 65 & 45 & 117 & 83 & 0 & 0 \\
\hline
\end{tabular}

Cabbage seedlings were manually transplanted at 8 weeks old at 40,000 plants ha $^{-1}$ (four rows per plot) on May 4, 2010 and April 7, 2011. The cabbages were fertilized with 120:65:45 $\mathrm{kg} \mathrm{ha}^{-1} \mathrm{~N}: \mathrm{P}: \mathrm{K}^{40}$ using the same products as in the corn. The fertilizer combinations to meet this nutrient requirement for cabbage are shown in Table 3. Fertilizers were applied in a similar way as for corn and irrigated by drip irrigation. Gypsum was applied $\left(333 \mathrm{kgha}^{-1}\right)$ as a sulfur supplement in mid-June to all plots (Table 3). Weeds in conventional plots were managed by manually pulling out the weeds with minimum soil disturbance at 3 and 7 weeks after transplanting. Weeds in organic plots were managed using a chipping hoe at 3 and 7 weeks after transplanting. In all plots, cabbage moth (Mamestra brassicae L.) and cabbage white butterfly (Pieris brassicae L.) caterpillars were controlled using Dipel ${ }^{\circledR}$ (active ingredient $=4320$ international units of potency $\mathrm{mg}^{-1}$ of Bacillus thuringiensis var. kurstaki) twice in September 2010 with a 15-day interval, but there was no need for insect control with the 2011 crop.

\section{Crop and weed sampling and determination of dry weights}

Both corn and cabbage were harvested manually from $1 \mathrm{~m} \times 1 \mathrm{~m}$ random quadrats in the two center rows, maintaining $0.5 \mathrm{~m}$ edge buffers on four sides of each plot. From each plot, corn cobs and stover were collected separately. Corn cobs were removed and the remaining plant parts (stover) were collected by cutting the plant at the soil surface. Any fallen leaves of corn were collected with the stover and not mixed with weeds. From each of the crop harvested-quadrats, all weeds were collected by cutting at ground level. The fresh weights of all components were measured, oven-dried at $70^{\circ} \mathrm{C}$ to a constant weight and reweighed.

Cabbages were harvested with one inner wrapper leaf on both sides of the head. From each plot, cabbage heads and weed biomass were collected on October 14, 2010 and September 16, 2011 from a $1 \mathrm{~m} \times 1 \mathrm{~m}$ random quadrat. The fresh weight of each component was measured, ovendried at $70^{\circ} \mathrm{C}$ to a constant weight and reweighed.

Plant tissue analysis. A ground $(<0.5 \mathrm{~mm})$ sub-sample of cabbage head was used to determine the concentrations of total $\mathrm{P}$ and $\mathrm{K}$ with an inductively coupled plasmaoptical emission spectrometer (ICP-OES) after extraction with a 7:3 70\% perchloric acid $/ 30 \%$ hydrogen peroxide solution using a sealed chamber digestion method ${ }^{41}$. Another sub-sample $(<0.5 \mathrm{~mm})$ of the dried plant samples was analyzed by a complete combustion method at $950^{\circ} \mathrm{C}$ in a furnace (TruSpec Carbon and Nitrogen Analyser, LECO Corporation) for determination of total $\mathrm{N}$. Nutrient uptake by cabbage heads was calculated by multiplying the measured nutrient concentrations with the corresponding dry biomass.

\section{Soil analyses}

Two gram of air-dried soil $(<2 \mathrm{~mm})$ was tumbled with $40 \mathrm{ml}$ of $1 \mathrm{M} \mathrm{NH}_{4} \mathrm{Cl}$ adjusted to $\mathrm{pH} 7$ (with $20 \% \mathrm{NH}_{4} \mathrm{OH}$ ) for $1 \mathrm{~h}$ and filtered through a Whatman No. 42 filter $^{42}$. The filtrate was analyzed in the ICP-OES for the determination of exchangeable cations $\mathrm{Ca}, \mathrm{Mg}, \mathrm{Na}$ and $\mathrm{K}$. Total $\mathrm{N}$ was determined on air-dried samples $(<0.5 \mathrm{~mm})$ by the same method as mentioned for the plant tissue analysis. Ammonium $\mathrm{N}$ was determined after extraction with $2 \mathrm{M} \mathrm{KCl}^{43}$. Colwell $\mathrm{P}$ was determined in a $0.5 \mathrm{M} \mathrm{NaHCO}_{3}(\mathrm{pH}$ of 8.5$)$ extract that was shaken with $1 \mathrm{M} \mathrm{H}_{2} \mathrm{SO}_{4}$ acid, followed by additions of polyvinyl alcohol and malachite green reagent, and absorbance measured on a spectrophotometer at $630 \mathrm{~nm}^{44}$.

\section{Statistical analysis}

A four-way analysis of variance (ANOVA) was used to assess the effects of residue management, SMS, soil type and year on the yield components of corn and cabbage, weed biomass, nutrient uptake (N, P and $\mathrm{K}$ ) by cabbage heads and soil nutrients using $\mathrm{R}$ version $2.11^{45}$. 
Table 4. Effect of soil type and SMS treatments on corn stover and cob yields in 2010 and 2011. Means $\pm 95 \%$ confidence intervals shown. Conv \pm RES = conventional soil management treatments with or without residue incorporation; Org \pm RES $=$ organic soil management treatments with or without residue incorporation.

\begin{tabular}{|c|c|c|c|c|}
\hline & \multicolumn{2}{|c|}{ Corn stover yield as dry weight $\left(\right.$ tha $\left.^{-1}\right)$} & \multicolumn{2}{|c|}{ Corn cob yield as dry weight $\left(\mathrm{tha}^{-1}\right)$} \\
\hline & Chromosol & Vertosol & Chromosol & Vertosol \\
\hline \multicolumn{5}{|l|}{2010} \\
\hline Conv & $14.0 \pm 2.30$ & $14.0 \pm 1.67$ & $3.70 \pm 1.003$ & $2.44 \pm 0.536$ \\
\hline Org & $14.8 \pm 2.49$ & $13.7 \pm 1.51$ & $2.76 \pm 0.799$ & $2.59 \pm 0.708$ \\
\hline \multicolumn{5}{|l|}{2011} \\
\hline Conv - RES & $8.16 \pm 0.836$ & $3.57 \pm 0.634$ & $7.37 \pm 2.54$ & $2.94 \pm 2.05$ \\
\hline Conv + RES & $8.37 \pm 1.942$ & $3.41 \pm 2.069$ & $9.23 \pm 2.16$ & $2.91 \pm 1.69$ \\
\hline Org - RES & $9.20 \pm 0.698$ & $3.26 \pm 0.760$ & $8.99 \pm 1.08$ & $2.30 \pm 0.30$ \\
\hline Org + RES & $8.66 \pm 0.495$ & $3.44 \pm 0.836$ & $7.16 \pm 1.55$ & $2.60 \pm 1.02$ \\
\hline
\end{tabular}

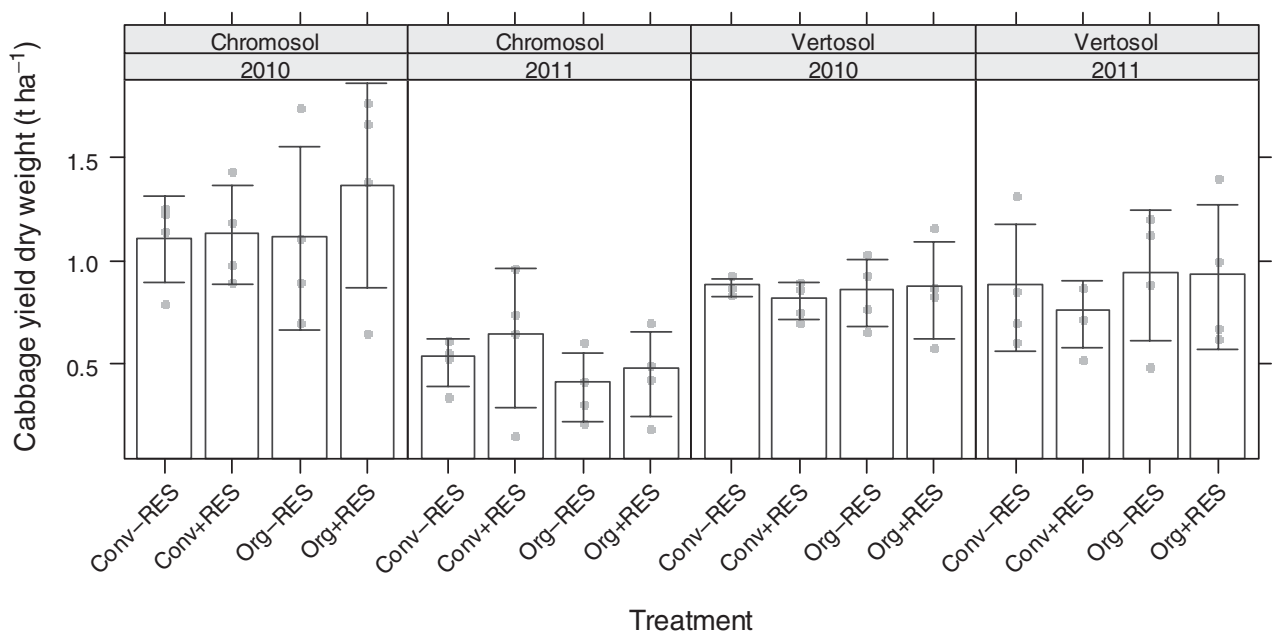

Figure 2. Effect of soil type, residue and SMS treatments on cabbage yield in 2010 and 2011 . Means $\pm 95 \%$ confidence intervals shown. Gray dots are raw data points. Conv \pm RES=conventional soil management treatments with or without residue incorporation; Org $\pm \mathrm{RES}=$ organic soil management treatments with or without residue incorporation.

Variance homogeneity was checked by plotting residual versus fitted values and the $q-q$ plots to assess the normality assumptions of ANOVA. Data were transformed to stabilize variance where assumptions were not met. $P$ values $<0.05$ were considered significant. Mean values of data are presented along with $95 \%$ confidence intervals (standard error $\times 1.96)^{46}$.

\section{Results}

\section{Corn phases}

Cob and stover yields are reported as dry weights only to compensate for differences in moisture content. The ANOVA on the cob and stover yield was performed on $\log$ transformed data to stabilize variances. Note that no residue had been applied to the field sites during the 2010 corn cropping period because it was the first season of corn. Corn stover and cob yields (Table 4) varied significantly for soil type and year as did their interaction
$(P<0.001)$. All other main terms and interactions terms were not significant. Stover yield was reduced in 2011 compared with 2010 by $40 \%\left(5.8 \mathrm{tha}^{-1}\right)$ in the Chromosol and by $75 \%\left(10.5 \mathrm{tha}^{-1}\right)$ in the Vertosol due to heavy rain during the crop establishment phase. Cob yield was increased in 2011 compared with 2010 by $153 \%$ in the Chromosol; however, the corresponding increase was only $14 \%$ in the Vertosol site.

\section{Cabbage phases}

As for corn, only dry weights are reported for cabbage yield and weed biomass. The dry matter of cabbage heads was highly influenced by year $(P<0.001)$, but the other terms were not significant (Fig. 2). The only significant interaction was between soil type and year $(P<0.001)$. The average cabbage yield decreased by $58 \%$ in 2011 in the Chromosol site but there was an increase of 3\% at the Vertosol site over the same period. There was a very low correlation between the cabbage yield and weed biomass 


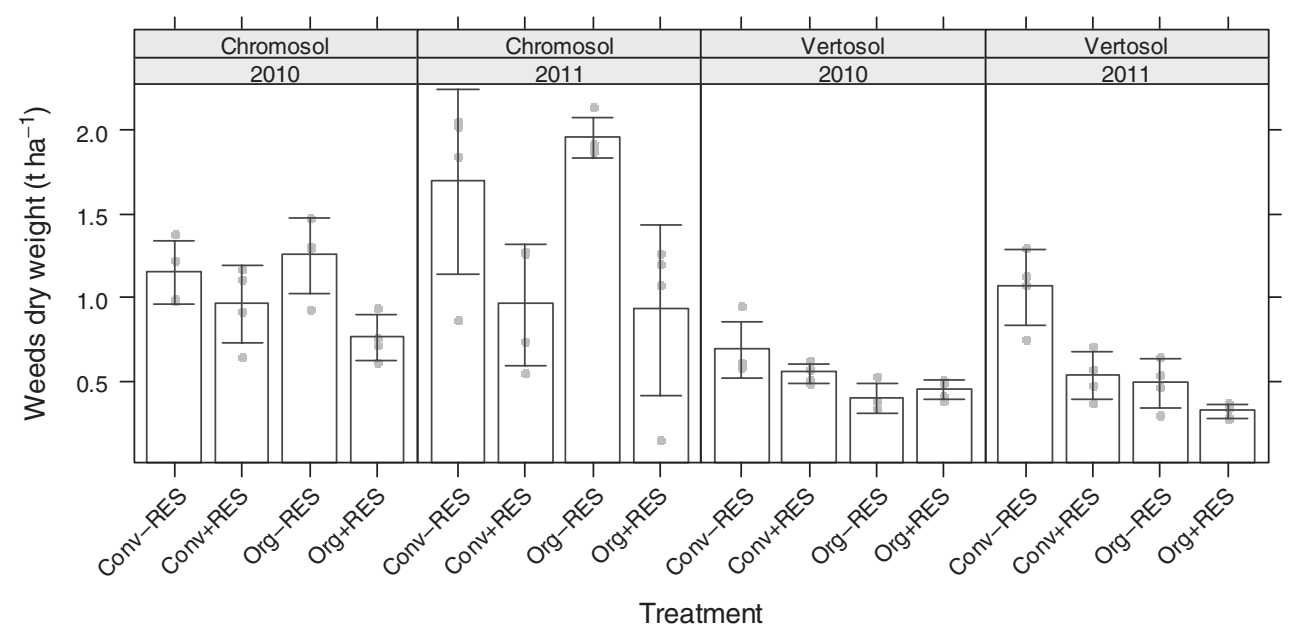

Figure 3. Effect of soil type, residue and SMS treatments on in-crop weed biomass in cabbage in 2010 and 2011 . Gray dots are raw data points. Means $\pm 95 \%$ confidence intervals shown. Conv \pm RES $=$ conventional soil management treatments with or without residue incorporation; Org \pm RES = organic soil management treatments with or without residue incorporation.

$\left(r^{2}=0.05\right)$ suggesting that the presence of weeds did not affect cabbage yield.

Weeds in cabbage. The ANOVA of weed biomass in cabbage was performed on log transformed data. Weed biomass was significant $(P<0.001)$ for the residue incorporation. Soil type was significant $(P<0.01)$ for the SMS (Fig. 3). The only two interactions, SMS $\times$ soil type $(P<0.05)$ and residue $\times$ year $(P<0.01)$ were significant. The role of incorporated residue as a management tool for weed suppression was evident by the fact that the residue incorporated treatments reduced the average weed biomass by $37 \%$ compared with the treatments without residue. Average weed biomass in the conventional SMS was reduced by $41 \%$ in the Vertosol site compared with the Chromosol site. However, in the organic SMS, the corresponding reduction was much higher at $66 \%$. The most dominant weed species in the Chromosol site was shepherd's purse (Capsella bursa-pastoris L.) followed by deadnettle (Lamium amplexicaule L.) and the most dominant weed at the Vertosol site was deadnettle followed by wireweed (Polygonum aviculare L.).

Nutrient uptake by cabbage heads. Uptake of N, P and K by cabbage heads is presented in Table 5. The ANOVA for the N, P and K uptake by cabbage head showed that none of the main terms were significant, nor were any interactions except for the soil type $\times$ year, which was significant at $P<0.01$. The average uptake of $\mathrm{N}, \mathrm{P}$ and $\mathrm{K}$ in the Chromosol site was reduced by 27,19 and $32 \%$, respectively, in 2011, whereas there was an increase of 49 , 45 and $31 \%$, respectively in the Vertosol site, compared with 2010 .

\section{Effect of treatments on soil properties}

Total- and ammonium-N and Colwell P. Soil total N status after cabbage harvest varied significantly for residue and soil type $(P<0.001)$, and for the SMS and year $(P<0.05)$
(Table 6). No interaction terms were significant. The residue incorporated treatments, on average, increased total $\mathrm{N}$ by $7 \%$ compared with the treatments without residue. The difference in soil type was a result of the Vertosol having $77 \%$ more total $\mathrm{N}$ compared to the Chromosol. The organic SMS had 3.6\% total N compared with the conventional SMS. Between the 2 years, 2011 had $4.3 \%$ more total $\mathrm{N}$ than in 2010 .

Ammonium-N was significantly $(P<0.01)$ influenced by residue treatment and by the year (Table 6 ). No other main terms and interactions were significant. The residue incorporated treatments had 39\% more $\mathrm{NH}_{4}-\mathrm{N}$ than the treatments without residue. Between the 2 years, there was $35 \%$ more $\mathrm{NH}_{4}-\mathrm{N}$ in 2011 compared with the values in 2010. Owing to the use of air-dried samples $\mathrm{NO}_{3}-\mathrm{N}$ measured was negligible and is not reported.

Colwell $\mathrm{P}$ in soil was significantly $(P<0.001)$ influenced by soil and year (Table 6). No other main terms and interactions were significant. The Vertosol site had $153 \%$ more Colwell $\mathrm{P}$ than the Chromosol site. There was a 43\% increase in Colwell $\mathrm{P}$ values for 2011 than for 2010.

Exchangeable cations. Exchangeable $\mathrm{Ca}$ and $\mathrm{Mg}$ in soil were highly influenced by soil type and year $(P<0.001)$ and there was a significant interaction $(P<0.001$ for $\mathrm{Ca}$ and $P<0.05$ for $\mathrm{Mg}$ ) (Table 6). Other factors and interactions were not significant for exchangeable $\mathrm{Ca}$ and $\mathrm{Mg}$. On average, exchangeable $\mathrm{Ca}$ for 2010 was $17 \%$ lower than that for 2011 in the Chromosol; however, the Vertosol had $10 \%$ higher quantity of exchangeable $\mathrm{Ca}$ over the same period, which produced the significant interaction between soil and year. The significant interaction between soil and year for exchangeable $\mathrm{Mg}$ was due to $34 \%$ average reduction in 2011 compared to 2010 in the Chromosol, whereas there was an average reduction of $18 \%$ in the Vertosol. 
Table 5. Treatment means of nutrients uptake $\left(\mathrm{kgha}^{-1}\right)$ by cabbage heads for two soil types in 2010 and 2011. Means $\pm 95 \%$ confidence intervals (CI) shown. Conv \pm RES = conventional soil management treatments with or without residue incorporation; Org \pm RES = organic soil management treatments with or without residue incorporation.

\begin{tabular}{|c|c|c|c|c|c|c|}
\hline & \multicolumn{3}{|c|}{2010} & \multicolumn{3}{|c|}{2011} \\
\hline & $N$ & $\boldsymbol{P}$ & $\boldsymbol{K}$ & $N$ & $\boldsymbol{P}$ & $K$ \\
\hline \multicolumn{7}{|l|}{ Chromosol } \\
\hline Conv + RES & 20.7 & 3.9 & 30.3 & 21.0 & 4.3 & 28.6 \\
\hline Conv - RES & 18.6 & 3.7 & 22.3 & 14.8 & 3.2 & 18.3 \\
\hline Org + RES & 24.9 & 4.5 & 37.5 & 14.2 & 3.0 & 18.9 \\
\hline Org-RES & 20.6 & 4.0 & 30.5 & 11.7 & 2.6 & 16.5 \\
\hline $95 \%$ CI & \pm 2.62 & \pm 0.34 & \pm 6.10 & \pm 3.86 & \pm 0.73 & \pm 5.32 \\
\hline \multicolumn{7}{|l|}{ Vertosol } \\
\hline Conv + RES & 16.0 & 3.3 & 18.9 & 22.7 & 3.9 & 24.0 \\
\hline Conv - RES & 15.7 & 3.2 & 19.2 & 24.9 & 4.6 & 25.7 \\
\hline Org + RES & 16.1 & 3.2 & 21.5 & 25.3 & 5.3 & 28.9 \\
\hline Org-RES & 15.7 & 3.1 & 20.2 & 21.8 & 4.8 & 26.0 \\
\hline $95 \% \mathrm{CI}$ & \pm 0.20 & \pm 0.06 & \pm 1.17 & \pm 1.66 & \pm 0.54 & \pm 1.98 \\
\hline
\end{tabular}

Table 6. Soil nutrients and other properties for $0-0.1 \mathrm{~m}$ depth for the two sites by two sampling times. Treatment means with $95 \%$ confidence interval $(\mathrm{CI})$ of means presented. Conv \pm RES $=$ conventional soil management treatments with or without residue incorporation; Org \pm RES = organic soil management treatments with or without residue incorporation.

\begin{tabular}{|c|c|c|c|c|c|c|c|}
\hline & $\begin{array}{c}\text { Total N } \\
(\%)\end{array}$ & $\begin{array}{l}\mathrm{NH}_{4}-\mathrm{N} \\
\left(\mu \mathrm{gg}^{-1}\right)\end{array}$ & $\begin{array}{c}\text { Colwell P } \\
\left(\mu g^{-1}\right)\end{array}$ & $\begin{array}{c}\text { Exch. K } \\
\left(\mathrm{cmol}_{\mathrm{c}} \mathrm{kg}^{-1}\right)\end{array}$ & $\begin{array}{c}\text { Exch. Ca } \\
\left(\mathrm{cmol}_{\mathrm{c}} \mathrm{kg}^{-1}\right)\end{array}$ & $\begin{array}{c}\text { Exch. Mg } \\
\left(\mathrm{cmol}_{\mathrm{c}} \mathrm{kg}^{-1}\right)\end{array}$ & $\begin{array}{c}\text { Exch. } \mathrm{Na} \\
\left(\mathrm{cmol}_{\mathrm{c}} \mathrm{kg}^{-1}\right)\end{array}$ \\
\hline & \multicolumn{7}{|c|}{ Chromosol October 2010} \\
\hline Conv + RES & 0.117 & 3.75 & 28.26 & 0.269 & 2.36 & 0.95 & 0.040 \\
\hline Conv - RES & 0.120 & 2.78 & 31.87 & 0.211 & 2.43 & 0.76 & 0.032 \\
\hline Org + RES & 0.130 & 4.22 & 24.88 & 0.298 & 2.57 & 1.01 & 0.053 \\
\hline Org-RES & 0.125 & 3.60 & 26.30 & 0.181 & 2.51 & 0.91 & 0.053 \\
\hline \multirow[t]{2}{*}{$95 \% \mathrm{CI}$} & \pm 0.006 & \pm 0.587 & \pm 2.969 & \pm 0.052 & \pm 0.088 & \pm 0.106 & \pm 0.010 \\
\hline & \multicolumn{7}{|c|}{ Chromosol December 2011} \\
\hline Conv + RES & 0.134 & 5.42 & 42.41 & 0.287 & 2.03 & 0.59 & 0.076 \\
\hline Conv-RES & 0.120 & 2.99 & 39.95 & 0.242 & 1.80 & 0.56 & 0.083 \\
\hline Org + RES & 0.150 & 7.36 & 44.68 & 0.264 & 2.28 & 0.67 & 0.077 \\
\hline Org-RES & 0.133 & 3.71 & 40.48 & 0.265 & 2.11 & 0.57 & 0.090 \\
\hline \multirow[t]{2}{*}{$95 \% \mathrm{CI}$} & \pm 0.012 & \pm 1.908 & \pm 2.100 & \pm 0.018 & \pm 0.196 & \pm 0.049 & \pm 0.006 \\
\hline & \multicolumn{7}{|c|}{ Vertosol October 2010} \\
\hline Conv + RES & 0.236 & 4.79 & 66.93 & 1.053 & 22.27 & 16.99 & 0.237 \\
\hline Conv - RES & 0.221 & 3.93 & 74.39 & 0.548 & 22.37 & 19.08 & 0.260 \\
\hline Org + RES & 0.230 & 4.48 & 86.92 & 0.931 & 21.98 & 18.98 & 0.281 \\
\hline Org-RES & 0.221 & 4.46 & 66.17 & 0.527 & 22.50 & 16.90 & 0.308 \\
\hline \multirow[t]{2}{*}{$95 \% \mathrm{CI}$} & \pm 0.007 & \pm 0.352 & \pm 9.430 & \pm 0.262 & \pm 0.220 & \pm 1.180 & \pm 0.030 \\
\hline & \multicolumn{7}{|c|}{ Vertosol December 2011} \\
\hline Conv + RES & 0.236 & 7.54 & 105.61 & 0.712 & 26.53 & 14.70 & 0.207 \\
\hline Conv-RES & 0.217 & 4.12 & 101.33 & 0.401 & 26.60 & 14.72 & 0.216 \\
\hline Org + RES & 0.237 & 6.07 & 105.50 & 0.735 & 26.45 & 14.61 & 0.211 \\
\hline Org - RES & 0.229 & 5.82 & 99.49 & 0.534 & 27.06 & 14.71 & 0.225 \\
\hline $95 \% \mathrm{CI}$ & \pm 0.009 & \pm 1.375 & \pm 3.003 & \pm 0.155 & \pm 0.269 & \pm 0.047 & \pm 0.008 \\
\hline
\end{tabular}

Exchangeable $\mathrm{K}$ in the soil was significantly influenced by residue incorporation and soil type $(P<0.001)$ and by the year $(P<0.01)$ (Table 6). The two-way interactions, residue $\times$ soil type and soil type $\times$ year were highly significant $(P<0.001)$ and residue $\times$ year was moderately significant $(P<0.01)$. The increase of exchangeable $\mathrm{K}$ due to the incorporated residue was greater $(71 \%)$ in the Vertosol site than at the Chromosol site $(24 \%)$, on average. The increase in exchangeable $\mathrm{K}$ in 2010 due to residue incorporation was $74 \%$ in 2010 compared with the 
treatments without residue. The corresponding increase in 2011 was only $39 \%$, which is about half the increase in 2010 .

Exchangeable Na was significantly influenced by SMS $(P<0.01)$ and soil type $(P<0.001)$ (Table 6). The only two significant interactions were SMS $\times$ year $(P<0.05)$ and soil type $\times$ year $(P<0.001)$. On average, exchangeable $\mathrm{Na}$ in organic SMS was 22 and 3.5\% higher than conventional SMS in 2010 and 2011, respectively, which produced the significant interaction between SMS and year. Soil type and year significantly interacted because the average exchangeable $\mathrm{Na}$ increased by $84 \%$ in 2011 for the Chromosol, but decreased by $21 \%$ during the same time for the Vertosol.

\section{Discussion}

\section{Agronomic outcomes for corn and cabbage}

In a vegetable enterprise, sweet corn is a compatible rotation crop that not only has relatively high economic value, but also produces a large quantity of stover for retention on the soil surface or for incorporation in soil ${ }^{6,7}$ reducing the likelihood of declining SOM in vegetable systems ${ }^{10,11}$. In this study, there were no significant differences between the SMS treatments for yields of sweet corn cobs and stover, and cabbage head. This could partly be attributable to the equivalent quantities $\mathrm{N}, \mathrm{P}$ and $\mathrm{K}$ nutrients applied $^{35}$ to both the organic and conventional SMS. Crop yields in organic systems are generally lower than the yields from conventional systems, mainly due to use of readily soluble nutrients and use of pesticides in the latter system $^{23,47}$. Elsewhere average corn yield of a chiselplough-based organic system was reported to be $28 \%$ less than the no-till conventional system ${ }^{24}$. In another study, average corn yields of the organic systems were lower, similar and higher than the conventional systems for the initial 5-year phase, after a 5-year transition period and for five drought-year period, respectively in the Rodale Institute experiment ${ }^{23}$.

A meta-analysis comparing yield performance of organic and conventional vegetable production systems reported that, on average, yields in organic systems were $33 \%$ lower than conventional systems ${ }^{48}$. Lotter et al. ${ }^{49}$ suggested that improved soil water-holding capacity may be related to the higher organic yields in drier seasons, while crop losses due to weed competition may contribute to lower organic yields.

It should be noted that the short implementation period of the organic SMS (2 years) may not have been sufficient to produce the expected yield differences because the nutrient levels in the soils may not have reached the limiting levels upon imposition of the treatments ${ }^{48}$. Lower crop productivity in organic systems reported in literature could be ascribed to limited $\mathrm{N}$ supply restricting growth ${ }^{15}$.

In other studies, corn residue incorporation rates were reported to have no significant effect on wheat
(Triticum aestivum L.) grain yields in a 2-year study, but the chisel-plough treatment with $25-50 \%$ corn residue incorporation with $150 \mathrm{~kg} \mathrm{~N}^{-1}$ raised grain yields ${ }^{50}$. Contrastingly, Shafi et al. ${ }^{51}$ reported a significant increase in grain and stover yields of maize following a postharvest incorporation of corn residue in both years of a 2-year study. The limited effect of residue incorporation on yield of cabbage head may be attributed to high average C: $\mathrm{N}$ ratios of residue immobilizing $\mathrm{N}^{52,53}$.

Water did not easily drain away in the clay Vertosol $(42 \%(\mathrm{v} / \mathrm{v})$ water-holding capacity) compared with the sandy Chromosol $(16 \%(\mathrm{v} / \mathrm{v})$ water-holding capacity) where water drained away relatively quickly ${ }^{32}$ which caused the between-sites and between-years yield differences. In 2010, the Chromosol site was affected by frost during the grain-filling period while slight lodging hampered the crop at Vertosol site, manifesting as cob yield differences between the 2 years. Differences in cabbage yield between two sites and years could be attributed to the differences in weed competition as revealed by weed biomasses.

\section{Nutrient uptake}

Uptake of N, P and $\mathrm{K}$ by cabbage heads showed no significant difference between the SMS and residue management treatments. This finding is consistent with the literature on food nutrition, which commonly reports a lack of clear, consistent differences between the nutrient contents of organic and conventional produce ${ }^{29,30,54}$. A review of 223 studies comparing nutrient levels of organically and conventionally produced foods found no nutritional benefits except for higher $\mathrm{P}$ levels in organic food $^{54}$ and other authors have also reported similar findings ${ }^{29,30}$. However, we did not find such a difference possibly due to the short timeframe and equivalent $\mathrm{N}, \mathrm{P}$ and $\mathrm{K}$ applied for both organic and conventional SMS. A meta-analysis of 39 papers comparing nutrient composition reported that only nitrate was significantly lower in organic carrot, lettuce and potato, higher in organic spinach and not different for other nutrients ${ }^{30}$. In a more recent study, nitrate concentration in the edible parts was significantly lower in crops grown in organically fertilized plots, with a tendency for lower $\mathrm{N}$ and higher $\mathrm{P}$ content in organic crops cultivated in the same crop cycle ${ }^{28}$.

\section{Residue incorporation effects on weed biomass}

The in-crop weed biomass for cabbage was significantly reduced by residue incorporation. Similar to our finding, oilseed rape (Brassica napus L.) residue incorporation was reported to have reduced by $50-96 \%$ weed biomass in potato (Solanum tuberosum L.) crop $^{55}$. Reduction of weed biomass indicates the ability of decomposing corn residue to suppress of weeds $\mathrm{s}^{21,56,57}$. Therefore, crop residue incorporation could be a supplementary weed management 
strategy ${ }^{19,20}$ to mechanical cultivation available to organic growers $^{16,17}$. Such practice could possibly save on the costs of cultivation and herbicide in organic and conventional agriculture, respectively, which warrants more research.

Some authors have claimed that non-chemical weed control methods in cabbage such as mulching and cultivation are as effective as herbicides ${ }^{58}$. In slower growing crops such as corn and cabbage, the use of mulch for weed control can be cost effective, being cheaper than handweeding and more effective than common tillage practices $^{59}$. Weed biomass in the Vertosol was observed to be lower as the site has been intensively cropped for trials for several decades, whereas the Chromosol site was converted from pasture to infrequent cropping about 7 years prior to initiation of the experiment.

\section{Soil nutrients}

Soil total $\mathrm{N}$ was impacted positively by the incorporated residue and the SMS possibly due to $\mathrm{N}$ input through residue and organic fertilizers. While sources of $\mathrm{N}$ in organically grown crops affect crop productivity by limiting the amount of available $\mathrm{N}$ to meet the crop demand ${ }^{14,15}$, organic systems have the potential to meet the $\mathrm{N}$ requirement if sources of $\mathrm{N}$ (leys, N-rich residues and uncomposted manure), timing of supply and choices of crops are carefully matched ${ }^{15}$. Organic management is also reported to have significantly lower levels of nitrate and soluble $\mathrm{N}$ in soil compared with conventional management ${ }^{60}$. Furthermore, $\mathrm{N}$ mineralization rates of a conventional system have been reported to be $100 \%$ higher than an organic system ${ }^{25}$. Therefore, organic SMS is likely to hold more $\mathrm{N}$ to increase $\mathrm{N}$ use efficiency and at the same time reduce the losses of $\mathrm{N}$ into the environment.

The release of $\mathrm{N}$ from the decomposed residue increased the average total $\mathrm{N}$ and $\mathrm{NH}_{4}-\mathrm{N}$ levels compared with the treatments without residue. Owing to a cumulative effect across years, 2011 had higher total N and $\mathrm{NH}_{4}-\mathrm{N}$ levels than in 2010 , on average. This observation was possibly because the increase in soil temperature could have stimulated decomposition and microbial transformation of $\mathrm{N}$, as the soil samples in 2011 were collected in December, a relatively warmer month compared with October in 2010. The treatments in the Vertosol had higher levels of average total $\mathrm{N}$ due to the Vertosol's inherent higher $\mathrm{N}$ status than the Chromosol $^{32}$.

The effect of soil type is likely simply due to the nutrient-rich Vertosol having higher levels of Colwell $\mathrm{P}$ and exchangeable $\mathrm{K}$ compared with the relatively poor Chromosol. The effect of year may have been due to a cumulative effect similar to that mentioned for total $\mathrm{N}$ levels. While a timeframe of 2 years may be too short to produce significant changes in $\mathrm{P}$ levels, Nachimuthu et al. ${ }^{61}$ reported that there was a major overlap between
$\mathrm{P}$ inputs for organic and conventional vegetable farms in eastern Australia, since conventional vegetable farmers were also found to apply organic inputs such as green manure and composts. They also found high levels of labile $\mathrm{P}$ in both farming systems in all study sites and so concluded that the organic vegetable farms were not nutritionally deficient. In another study of organic vegetable production systems in Australia, two alternative vegetable systems that received high inputs of compost were reported to increase soil $\mathrm{C}$, total $\mathrm{N}$, total $\mathrm{P}$ and exchangeable cations compared with three conventional systems and the high mineral fertilizer recipient treatment had highest potentials to release $\mathrm{P}$ into the environment ${ }^{36}$. Vegetable systems in the greater Sydney metropolitan region of NSW are reported to accumulate exchangeable cations $(\mathrm{Ca}, \mathrm{Mg}$, and $\mathrm{K})$ and $\mathrm{P}$ as a consequence of high rates of inorganic fertilizers and poultry manure inputs as well as excessive cultivation ${ }^{11}$. Hence, to reduce the burden on external supply of organic materials to maintain soil fertility and to counteract the negative effect of excessive cultivation for weed control, sweet corn is suggested as a rotation crop in a vegetable system.

\section{Conclusion}

Yields of corn and cabbage under the organic SMS were equivalent to the conventional SMS. In other words, performance in the organic SMS can be matched to that in the conventional SMS if the macro-nutrients are balanced. The short experimental period of 2 years may have been insufficient to produce the anticipated yield differences reported in the literature. No clear difference in the nutrient uptake between the organic and conventional SMS was found and is consistent with the literature.

Corn residue-induced inhibitions on weed biomass may be used as a supplementary tool to mechanical weed control for organic SMS, potentially reducing the negative impacts of cultivation on SOC. Further, it could potentially reduce the costs of herbicides used in conventional SMS. Soil incorporation of residue and organic SMS are separately capable of improving total $\mathrm{N}$ and exchangeable $\mathrm{K}$, indicating the long-term fertility gains of these treatments. The slower nutrient releasing characteristics of organic fertilizer can not only reduce nutrient losses to the environment, but also benefit successive crops.

Acknowledgements. The principal author was funded by the Endeavour Postgraduate Award of Australia Awards, and the University of New England (UNE) and the Primary Industries Innovation Centre (a joint venture of NSW DPI and UNE). Agronomic support by Craig Birchall, biometrical guidance by Bruce McCorkell and technical assistance by Leanne Lisle, Michael Faint, David Edmonds, Greg Chamberlain, Gary Cluley, Jan Carruthers and George Henderson are gratefully acknowledged. Thanks to two anonymous reviewers for their valuable comments. 


\section{References}

1 Johnson, J.M.F., Franzluebbers, A.J., Weyers, S.L., and Reicosky, D.C. 2007. Agricultural opportunities to mitigate greenhouse gas emissions. Environmental Pollution 150: 107-124.

2 Luo, Z., Wang, E., and Sun, O.J. 2010. Soil carbon change and its responses to agricultural practices in Australian agro-ecosystems: A review and synthesis. Geoderma 155: 211-223.

3 Six, J., Elliott, E.T., and Paustian, K. 1999. Aggregate and soil organic matter dynamics under conventional and no-tillage systems. Soil Science Society of America Journal 63:1350-1358.

4 von Lützow, M., Kögel-Knabner, I., Ekschmitt, K., Matzner, E., Guggenberger, G., Marschner, B., and Flessa, H. 2006. Stabilization of organic matter in temperate soils: Mechanisms and their relevance under different soil conditions - a review. European Journal of Soil Science 57:426-445.

5 Wilhelm, W.W., Johnson, J.M.F., Hatfield, J.L., Voorhees, W.B., and Linden, D.R. 2004. Crop and soil productivity response to corn residue removal: A literature review. Agronomy Journal 96:1-17.

6 Yadvinder, S., Bijay, S., and Timsina, J. 2005. Crop residue management for nutrient cycling and improving soil productivity in rice-based cropping systems in the tropics. Advances in Agronomy 85:269-407.

7 Valzano, F., Murphy, B.W., and Koen, T. 2005. The Impact of Tillage on Changes in Soil Carbon Density with Special Emphasis on Australian Conditions, National Carbon Accounting System. Australian Greenhouse Office, Canberra.

8 Hoskinson, R.L., Karlen, D.L., Birrell, S.J., Radtke, C.W., and Wilhelm, W.W. 2007. Engineering, nutrient removal, and feedstock conversion evaluations of four corn stover harvest scenarios. Biomass and Bioenergy 31:126-136.

9 Johnson, J.M.F., Allmaras, R.R., and Reicosky, D.C. 2006. Estimating source carbon from crop residues, roots and rhizodeposits using the national grain-yield database. Agronomy Journal 98:622-636.

10 Jackson, L.E., Ramirez, I., Yokota, R., Fennimore, S.A., Koike, S.T., Henderson, D.M., Chaney, W.E., Calderón, F.J., and Klonsky, K. 2004. On-farm assessment of organic matter and tillage management on vegetable yield, soil, weeds, pests, and economics in California. Agriculture, Ecosystems and Environment 103:443-463.

11 Chan, K.Y., Dorahy, C.G., Tyler, S., Wells, A.T., Milham, P.P., and Barchia, I. 2007. Phosphorus accumulation and other changes in soil properties as a consequence of vegetable production, Sydney region, Australia. Soil Research 45:139-146.

12 Mondelaers, K., Aertsens, J., and Van Huylenbroeck, G. 2009. A meta-analysis of the differences in environmental impacts between organic and conventional farming. British Food Journal 111:1098-1119.

13 Chirinda, N., Olesen, J.E., Porter, J.R., and Schjønning, P. 2010. Soil properties, crop production and greenhouse gas emissions from organic and inorganic fertilizer-based arable cropping systems. Agriculture, Ecosystems and Environment 139:584-594.

14 Stockdale, E.A., Shepherd, M.A., Fortune, S., and Cuttle, S.P. 2002. Soil fertility in organic farming systems - fundamentally different? Soil Use and Management 18:301-308.

15 Berry, P.M., Sylvester-Bradley, R., Philipps, L., Hatch, D.J., Cuttle, S.P., Rayns, F.W., and Gosling, P. 2002. Is the productivity of organic farms restricted by the supply of available nitrogen? Soil Use and Management 18:248-255.

16 Bond, W. and Grundy, A.C. 2001. Non-chemical weed management in organic farming systems. Weed Research 41:383-405.

17 Turner, R.J., Davies, G., Moore, H., Grundy, A.C., and Mead, A. 2007. Organic weed management: A review of the current UK farmer perspective. Crop Protection 26:377-382.

18 Wood, R., Lenzen, M., Dey, C., and Lundie, S. 2006. A comparative study of some environmental impacts of conventional and organic farming in Australia. Agricultural Systems 89:324-348.

19 Fisk, J.W., Hesterman, O.B., Shrestha, A., Kells, J.J., Harwood, R.R., Squire, J.M., and Sheaffer, C.C. 2001. Weed suppression by annual legume cover crops in no-tillage corn. Agronomy Journal 93:319-325.

20 Mennan, H., Ngouajio, M., Kaya, E., and Isik, D. 2009. Weed management in organically grown kale using alternative cover cropping systems. Weed Technology 23:81-88.

21 Weston, L.A. 1996. Utilization of allelopathy for weed management in agroecosystems. Agronomy Journal 88:860-866.

22 Foley, J.A., Ramankutty, N., Brauman, K.A., Cassidy, E.S., Gerber, J.S., Johnston, M., Mueller, N.D., O'Connell, C., Ray, D.K., West, P.C., Balzer, C., Bennett, E.M., Carpenter, S.R., Hill, J., Monfreda, C., Polasky, S., Rockstrom, J., Sheehan, J., Siebert, S., Tilman, D., and Zaks, D.P.M. 2011. Solutions for a cultivated planet. Nature 478:337-342.

23 Pimentel, D., Hepperly, P., Hanson, J., Douds, D., and Seidel, R. 2005. Environmental, energetic, and economic comparisons of organic and conventional farming Systems. BioScience 55:573-582.

24 Teasdale, J.R., Coffman, C.B., and Mangum, R.W. 2007. Potential long-term benefits of no-tillage and organic cropping systems for grain production and soil improvement. Agronomy Journal 99:1297-1305.

25 Poudel, D.D., Horwath, W.R., Lanini, W.T., Temple, S.R., and van Bruggen, A.H.C. 2002. Comparison of soil $\mathrm{N}$ availability and leaching potential, crop yields and weeds in organic, low-input and conventional farming systems in northern California. Agriculture, Ecosystems and Environment 90:125-137.

26 Badgley, C., Moghtader, J., Quintero, E., Zakem, E., Chappell, M.J., Avilés-Vázquez, K., Samulon, A., and Perfecto, I. 2007. Organic agriculture and the global food supply. Renewable Agriculture and Food Systems 22: 86-108.

27 Trewavas, A. 2001. Urban myths of organic farming. Nature 410:409-410.

28 Herencia, J.F., García-Galavís, P.A., Dorado, J.A.R., and Maqueda, C. 2011. Comparison of nutritional quality of the crops grown in an organic and conventional fertilized soil. Scientia Horticulturae 129:882-888.

29 Biao, X., Xiaorong, W., Zhuhong, D., and Yaping, Y. 2003. Critical impact assessment of organic agriculture. Journal of Agricultural and Environmental Ethics 16:297-311.

30 Hoefkens, C., Vandekinderen, I., De Meulenaer, B., Devlieghere, F., Baert, K., Sioen, I., De Henauw, S., 
Verbeke, W., and Van Camp, J. 2009. A literature-based comparison of nutrient and contaminant contents between organic and conventional vegetables and potatoes. British Food Journal 111:1078-1097.

31 Rab, M., Fisher, P., and O'Halloran, N. 2008. Preliminary Estimation of the Carbon Footprint of the Australian Vegetable Industry, Discussion Paper 4. Victoria Department of Primary Industry, Tatura.

32 Isbell, R.F. 2002. The Australian Soil Classification. CSIRO Publishing, Melbourne.

33 Soil Survey Staff. 2010. Keys to Soil Taxonomy. Natural Resources Conservation Services of the United States Department of Agriculture, Washington, DC, USA.

34 Bureau of Meteorology. 2012. Climate Data Online. Bureau of Meteorology, Canberra. Available at Web site http://www. bom.gov.au/climate/data (verified July 31, 2012).

35 Hoffmann, S., Schulz, E., Csitári, G., and Bankó, L. 2006. Influence of mineral and organic fertilizers on soil organic carbon pools. Archives of Agronomy and Soil Science 52:627-635.

36 Wells, A.T., Chan, K.Y., and Cornish, P.S. 2000. Comparison of conventional and alternative vegetable farming systems on the properties of a yellow earth in New South Wales. Agriculture, Ecosystems and Environment 80:47-60.

37 Leifeld, J., Reiser, R., and Oberholzer, H.R. 2009. Consequences of conventional versus organic farming on soil carbon: Results from a 27-year field experiment. Agronomy Journal 101:1204-1218.

38 Marinari, S., Lagomarsino, A., Moscatelli, M.C., Di Tizio, A., and Campiglia, E. 2010. Soil carbon and nitrogen mineralization kinetics in organic and conventional three-year cropping systems. Soil and Tillage Research 109:161-168.

39 NSW DPI. 2009. Summer crop production guide 2009. NSW DPI, Orange. Available at Web site http://www.dpi.nsw.gov. au/agriculture/ (verified November 20, 2009).

40 NSW DPI. 2006. Cabbage growing, Primefact 90. NSW DPI, Orange. Available at Web site http://www.dpi.nsw.gov. au (verified January 18, 2010).

41 Anderson, D.L. and Henderson, L.J. 1986. Sealed chamber digestion for plant nutrient analysis. Agronomy Journal 78:937-938.

42 Rayment, G. and Higginson, F. 1992. Australian Laboratory Handbook of Soil and Water Chemical Method. Inkata Press, Port Melbourne.

43 Keeney, D.R. and Nelson, D.W. 1982. Nitrogen - inorganic forms. In A.L. Page (ed.). Methods of Soil Analysis. Part 2 Chemical and Microbiological Properties. Agronomy No. 9. ASA and SSSA Inc., Madison. p. 643-698.

44 Motomizu, S., Wakimoto, T., and Toei, K. 1983. Spectrophotometric determination of phosphate in river waters with molybdate and malachite green. Analyst 108:361-367.

45 R Development Core Team. 2010. R: A Language and Environment for Statistical Computing. R Foundation for Statistical Computing, Vienna.

46 Brandstätter, E. 1999. Confidence intervals as an alternative to significance testing. Methods of Psychological Research 4: online.

47 Azadi, H., Schoonbeek, S., Mahmoudi, H., Derudder, B., De Maeyer, P., and Witlox, F. 2011. Organic agriculture and sustainable food production system: Main potentials. Agriculture, Ecosystems and Environment 144: 92-94.

48 Seufert, V., Ramankutty, N., and Foley, J.A. 2012. Comparing the yields of organic and conventional agriculture. Nature 485:229-232.

49 Lotter, D.W., Seidel, R., and Liebhardt, W. 2003. The performance of organic and conventional cropping systems in an extreme climate year. American Journal of Alternative Agriculture 18:146-154.

50 Alijani, K., Bahrani, M.J., and Kazemeini, S.A. 2012. Shortterm responses of soil and wheat yield to tillage, corn residue management and nitrogen fertilization. Soil and Tillage Research 124:78-82.

51 Shafi, M., Bakht, J., Jan, M.T., and Shah, Z. 2007. Soil $\mathrm{C}$ and $\mathrm{N}$ dynamics and maize (Zea may L.) yield as affected by cropping systems and residue management in North-western Pakistan. Soil and Tillage Research 94:520-529.

52 Moritsuka, N., Yanai, J., Mori, K., and Kosaki, T. 2004. Biotic and abiotic processes of nitrogen immobilization in the soil-residue interface. Soil Biology and Biochemistry 36:1141-1148.

53 Trinsoutrot, I., Recous, S., Bentz, B., Lineres, M., Cheneby, D., and Nicolardot, B. 2000. Biochemical quality of crop residues and carbon and nitrogen mineralization kinetics under nonlimiting nitrogen conditions. Soil Science Society of America Journal 64:918-926.

54 Smith-Spangler, C., Brandeau, M.L., Hunter, G.E., Bavinger, J.C., Pearson, M., Eschbach, P.J., Sundaram, V., Liu, H., Schirmer, P., Stave, C., Olkin, I., and Bravata, D.M. 2012. Are organic foods safer or healthier than conventional alternatives? A systematic review. Annals of Internal Medicine 157:348-366.

55 Boydston, R.A. and Hang, A. 1995. Rapeseed (Brassica napus) green manure crop suppresses weeds in potato (Solanum tuberosum). Weed Technology 9:669-675.

56 Cheema, Z.A. and Khaliq, A. 2000. Use of sorghum allelopathic properties to control weeds in irrigated wheat in a semi arid region of Punjab. Agriculture, Ecosystems and Environment 79:105-112.

57 Gallandt, E.R., Liebman, M., and Huggins, D.R. 1999. Improving soil quality: Implications for weed management. Journal of Crop Production 2:95-121.

58 Dillard, H.R., Bellinder, R.R., and Shah, D.A. 2004. Integrated management of weeds and diseases in a cabbage cropping system. Crop Protection 23:163-168.

59 Kristiansen, P.E., Sindel, B.M., and Jessop, R.S. 2008. Weed management in organic echinacea (Echinacea purpurea) and lettuce (Lactuca sativa) production. Renewable Agriculture and Food Systems 23:120-135.

60 van Diepeningen, A.D., de Vos, O.J., Korthals, G.W., and van Bruggen, A.H.C. 2006. Effects of organic versus conventional management on chemical and biological parameters in agricultural soils. Applied Soil Ecology 31:120-135.

61 Nachimuthu, G., Kristiansen, P., Guppy, C., Lockwood, P., and King, K. 2012. Organic vegetable farms are not nutritionally disadvantaged compared with adjacent conventional or integrated vegetable farms in Eastern Australia. Scientia Horticulturae 146:164-168. 